\title{
Linkage Analysis of von Recklinghausen Neurofibromatosis to DNA Markers on Chromosome 17
}

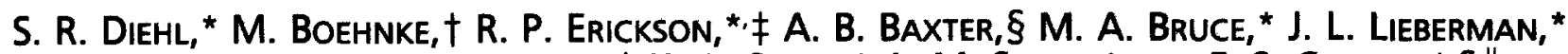 \\ D. J. Platt, * L. M. Ploughman, † K. A. Seller, * A. M. Sweet, ${ }^{\star}$ and F. S. Collins, ${ }^{\star}, \xi^{\prime \prime}$ \\ Departments of *Human Genetics, †Biostatistics, §Internal Medicine, $¥$ Pediatrics and Communicable Diseases, \\ and the |Howard Hughes Medical Institute, University of Michigan, Ann Arbor, Michigan 48109
}

Received November 16, 1987; revised December 16, 1987

\begin{abstract}
Several recent studies indicate that the von Recklinghausen neurofibromatosis (NF1) gene is located near the centromere of chromosome 17 in some families. However, variable expressivity and a very high mutation rate suggest that defects at several different loci could result in phenotypes categorized as NF1. In order to assess this possibility and to map the NF1 gene more precisely, we have used two polymorphic DNA markers from chromosome 17 to screen several pedigrees for linkage to NF 1. We ascertained a large Caucasian pedigree (33 individuals sampled, 17 NF1 affected) as well as eight smaller pedigrees and nuclear families (50 individuals sampled, 30 NF1 affected). Here, we report strong evidence of linkage of NF1 to the centromeric marker D17Z1 (maximum lod $=4.42$ ) and a weaker suggestion of linkage to the ERBA1 oncogene (maximum lod $=0.57$ ), both at a recombination fraction of zero. Since obligate crossovers with NF1 were not observed for either marker in any of the informative families tested, the possibility of NF 1 locus heterogeneity is not supported. (c) 1987 Academic Press, Inc.
\end{abstract}

\section{INTRODUCTION}

We have previously excluded linkage of NF1 to a substantial portion of chromosome 8 in a large American Caucasian pedigree (Diehl et al., 1987). These data contributed to an exclusion map for NF1 (Sarfarazi et al., 1987). The results of this pooled set of mapping data, especially a positive lod score of 1.17 at a recombination fraction of 0.1 (Barker et al., 1987a) for linkage near the centromere of chromosome 17 (D17Z1), suggested this chromosome as one of the most likely map locations for the NF1 gene. This suggestion was confirmed by conclusive reports of linkage to markers from chromosome 17 , including the centromeric marker D17Z1 and pA10-41 (Barker et al., 1987b) and the nerve growth factor receptor (Seizinger et al., 1987). However, variable expressivity and a very high mutation rate of NF1 may be indicative of locus heterogeneity for this disease. Among the individual families examined in these previous studies, the largest two-point lod score was 1.46 , and some families exhibited slightly negative lod scores. Therefore, we have undertaken additional linkage studies using chromosome 17 markers. Our goal is to evaluate further the possibility of locus heterogeneity and to map precisely the NF1 gene for improved diagnostic accuracy and to facilitate its cloning and characterization.

\section{METHODS AND STUDY SUBJECT}

A total of nine American Caucasian NF1 pedigrees were ascertained and diagnostic examinations were performed. Individuals were categorized as affected with NF1 if two or more of the following criteria were satisfied: (1) six café-au-lait macules greater than 1.5 $\mathrm{cm}$ in diameter for postpubertal individuals or five macules greater than $0.5 \mathrm{~cm}$ in diameter before puberty; (2) one or more neurofibromas (one, if histologically confirmed), including plexiform; (3) multiple freckles of axilla or groin; (4) two or more Lisch nodules; (5) one or more optic nerve gliomas; (6) characteristic bony changes (Holt, 1978); and (7) a first-degree relative affected with NF1. In no instance did we observe nonpenetrant individuals who passed the NF1 gene to an affected offspring. Blood samples were drawn and immortalized cell lines were established using Epstein-Barr virus transformation. DNA was extracted using a method described by Bell et al. (1981). Restriction endonuclease digestions, Southern blotting, and hybridizations were carried out using conventional methods (Davis et al., 1986; Feinberg 
TABLE 1

Lod Scores for von Recklinghausen Neurofibromatosis Chromosome 17 Markers

\begin{tabular}{|c|c|c|c|c|c|c|c|}
\hline \multirow[b]{2}{*}{ Family } & \multicolumn{7}{|c|}{ Recombination fraction $(\theta)$} \\
\hline & 0.00 & 0.01 & 0.05 & 0.10 & 0.20 & 0.30 & 0.40 \\
\hline \multicolumn{8}{|c|}{$\mathrm{D} 17 \mathrm{Z} 1(E c o R \mathrm{I})$} \\
\hline UMI1 & 2.60 & 2.54 & 2.33 & 2.05 & 1.49 & 0.92 & 0.41 \\
\hline UMI2 & 0.09 & 0.08 & 0.07 & 005 & 0.03 & 0.01 & 0.00 \\
\hline UMI3 & 0.84 & 0.82 & 0.73 & 0.63 & 0.41 & 0.20 & 0.05 \\
\hline UMI4 & 0.30 & 0.29 & 0.26 & 0.21 & 0.13 & 0.06 & 0.02 \\
\hline UMI5 & 0.30 & 0.29 & 0.26 & 0.21 & 0.13 & 0.06 & 0.02 \\
\hline UMI8 & 0.30 & 0.29 & 0.26 & 0.21 & 0.13 & 0.06 & 0.02 \\
\hline Total & 4.42 & 4.32 & 3.90 & 3.38 & 2.32 & 1.33 & 0.52 \\
\hline \multicolumn{8}{|c|}{ erbA1 (PvuII and $E c o \mathrm{RI})$} \\
\hline UMI1 & 0.54 & 0.53 & 0.49 & 0.44 & 0.32 & 0.21 & 0.10 \\
\hline UMI2 & 0.03 & 0.03 & 0.02 & 0.02 & 0.01 & 0.00 & 0.00 \\
\hline Total & 0.57 & 0.56 & 0.51 & 0.45 & 0.33 & 0.22 & 0.10 \\
\hline
\end{tabular}

and Vogelstein, 1984). Linkage to NF1 was tested for the centromeric marker D17Z1 using the clone $\mathrm{p} 17 \mathrm{H} 8$, which is polymorphic when tested with the restriction enzyme EcoRI (Willard et al., 1986), and the ERBA1 oncogene, which is polymorphic for EcoRI when tested with the clone pE2A3D (MathieuMahul et al., 1985) and for PvuII when tested with the clone pHE-A1 (Rider et al., 1987). Linkage analyses to other chromosome 17 markers using some of our NF1 families are reported by Stephens et al. (this volume).

A total of 77 individuals (46 NF1 affected) were codominantly genotyped for D17Z1, 80 individuals (46 NF1 affected) for the ERBA1 EcoRI polymorphism, and 59 individuals (37 NF1 affected) for the ERBA1 $P v u I I$ polymorphism. EcoRI and PvuII polymorphisms for ERBA1 were combined into haplotypes for linkage analysis. We assumed a linear increase of penetrance of NF1 from $0 \%$ at birth to $95 \%$ at age 6 years and thereafter.

\section{RESULTS}

The results of our linkage analysis, presented as lod scores (Morton, 1955) calculated using the program LIPED (Ott, 1974), are presented in Table 1. No obligate crossovers were observed between either of the markers and NF1 in any of the families tested. Maximum lod scores consequently were estimated at a recombination fraction of zero for both markers. There was no obvious difference in the number of informative male and female meioses in the data, so the observed absence of crossovers cannot be attributed to sex-specific differences in recombination rates. The centromeric marker D17Z1 was most informative and yielded a lod score of 4.42 for all families combined. Family UMI1 alone (33 individuals scored, 17 NF1 affected) provided a lod score of 2.60 for linkage between D17Z1 and NF1, which is close to the accepted criterion of 3.0 for demonstration of linkage. The ERBA1 polymorphisms were much less informative, yielding only a combined lod score of 0.57 . The degree to which these markers were informative corresponds to the observed frequencies of their alleles. Based on the counting of about 50 independent alleles, the three alleles that we observed for D17Z1 ( $2.7 \mathrm{~kb}$ only; $2.7,2.0$, and $1.5 \mathrm{~kb} ; 2.7$ and $1.5 \mathrm{~kb}$ ) exhibited frequencies of $0.71,0.27$, and 0.02 , respectively. In contrast, both ERBA1 polymorphisms consisted of two alleles with frequencies of about 0.96 and 0.04 (respectively, $E c o$ RI: 8.5 or $20.0 \mathrm{~kb}$; Pvu II: $1.2,0.8$, or $2.0 \mathrm{~kb}$ ). Polymorphisms at the two enzymes utilized for the ERBA1 probe were not in complete disequilibrium.

\section{DISCUSSION}

Our results broaden the conclusion of linkage of NF1 to the pericentromeric region of chromosome 17. The complete absence of obligate crossovers in any of the informative families here analyzed reduces the likelihood that locus heterogeneity is a common source of the observed variable expressivity or high mutation rate of NF1.

\section{ACKNOWLEDGMENTS}

We thank $\mathrm{H}$. Willard for providing the D17Z1 DNA clone, S. Saule and D. Stehelin for the ERBA1 clones, and K. Stephens (Collaborative Research Inc.) for establishing cell lines in families UMI4-UMI9. Our work was supported by NIH Grant NS23410. F.S.C. is an investigator of the Howard Hughes Medical Institute.

\section{REFERENCES}

1. Barker, D., Wright, E., Nguyen, K., Cannon, L., Fain, P., et al. (1987a). A genomic search for linkage of neurofibromatosis to RFLPs. J. Med. Genet. 24: 536-538.

2. Barker, D., Wright, E., Nguyen, K., Cannon, L., Fain, P., et al. (1987b). Gene for von Recklinghausen neurofibromatosis is in the pericentromeric region of chromosome 17. Science 236: $1100-1102$.

3. Bell, G. I., Karam, J. H., ANd RutTer, W. J. (1981). Polymorphic DNA region adjacent to the $5^{\prime}$ end of the human insulin gene. Proc. Natl. Acad. Sci. USA 78: 5759-5763.

4. Davis, L. G., Dibner, M. D., AND BatTey, J. F. (1986). "Basic Methods in Molecular Biology," Elsevier, New York.

5. Diehl, S. R., Boehnke, M., Collins, F. S., Erickson, R. P., KAROLYI, I. J., et al. (1987). Linkage analysis of peripheral neurofibromatosis to DNA markers on chromosome 8. J. Med. Genet. 24: 532-534.

6. Feinberg, A. P., ANd Vogelstein, B. (1984). A technique for radiolabeling DNA restriction endonuclease fragments to high specific activity. Anal. Biochem. 137: 266-267. 
7. HoLT, J. F. (1978). Neurofibromatosis in children. Amer, J. Roentgenol. 130: 615-639.

8. Mathieu-Mahul, D., Xu, D. Q., Saule, S., Lidereau, R., GALIBERT, F., et al. (1985). An EcoRI restriction fragment length polymorphism (RFLP) in the human c-erb A locus. Hum. Genet. 71: 41-44.

9. Morton, N. E. (1955). Sequential tests for the detection of linkage. Amer. J. Hum. Genet. 7: 277-318.

10. ОтT, J. (1974). Estimation of the recombination fraction in human pedigrees: Efficient computation of the likelihood for human linkage studies. Amer. J. Hum. Genet. 26: 588-597.

11. Rider, S. H., Bailey, C. J., Voss, R., SheER, D., Hiorns, L. R., AND SOLOMON, E. (1987). RFLP for the human erb-A1 gene. Nucleic Acids Res. 15: 863.

12. Sarfarazi, M., Huson, S. M., and Edwards, J. H. (1987).
An exclusion map for von Recklinghausen neurofibromatosis. J. Med. Genet. 24: 515-520.

13. SEIZINGER, B. R., and 32 other authors. (1987). Genetic linkage of von Recklinghausen neurofibromatosis to the nerve growth factor receptor gene. Cell 49: 589-594.

14. Stephens, K., RicCardi, V. M., Rising, M., NG, S., GreEN, P., Collins, F. S., Rediker, K. S., Powers, J. A., Parker, C., AND DoNIS-KELLER, H. (1987). Linkage studies with chromosome 17 DNA markers in 45 neurofibromatosis 1 families. Genomics 1, 353-357.

15. Willard, H. F., Waye, J. S., Skolnick, M. H., SchwartZ, C. E., PowERs, V. E., AND ENGLAND, S. B. (1986). Detection of restriction fragment length polymorphisms at the centromeres of human chromosomes by using chromosome-specific $\alpha$ satellite DNA probes: Implications for development of centromere-based genetic linkage maps. Proc. Natl. Acad. Sci. USA 83: 5611-5615. 